\title{
Involvement of mitochondria in apoptosis of cancer cells induced by photodynamic therapy
}

\section{Envolvimento da mitocôndria em apoptose de células cancerígenas induzida por terapia fotodinâmica}

Joselito Nardy Ribeiro'; André Romero da Silva'; Renato Atilio Jorge²

\begin{abstract}
key words abstract
Photodynamic therapy

Apoptosis

Mitochondria

Photodynamic therapy (PDT), a promising cancer treatment that employs a combination of a photosensitizing chemical, oxygen, and visible light, induces apoptosis in tumor cells. However, the precise mechanism of PDT-induced apoptosis is not well characterized. Many of the photosensitizers currently in clinical or preclinical studies of PDT are localized in or have a major influence on mitochondria. The treatment with PDT causes mitochondrial damage and induces apoptosis through the release of cytochrome c (cyt c), apoptosisinducing factor (AIF), Smac/DIABLO and certain procaspases. Proapoptotic and antiapoptotic members of $B C L-2$ family regulate the release of these proteins from mitochondria. The purpose of this mini-review is to present some recent publications that focus on the involvement of the mitochondria in apoptosis of cancer cells induced by PDT.
\end{abstract}

resumo

A terapia fotodinâmica (TFD) é um promissor tratamento clínico que emprega a combinação de luz visível, oxigênio e uma substância fotossensibilizadora para tratar doenças de caráter oncológico. Esse tipo de tratamento induz a morte celular programada (apoptose) em tecido tumoral. No entanto, o mecanismo de indução de apoptose por TFD não está bem caracterizado. Muitos fotossensibilizadores possuem como alvo principal a mitocôndria. O tratamento com TFD causa danos nessa organela e induz a apoptose através da liberação de citocromo $c$, fator de indução de apoptose, Smac/DIABLO e certas pró-caspases. A liberação dessas proteínas, a partir da mitocôndria, é regulada por uma família de proteínas pró e antiapoptóticas, conhecida como família BCL-2. A proposta dessa minirrevisão é apresentar algumas publicações recentes que focalizam o envolvimento da mitocôndria em apoptose de células cancerígenas induzida por TFD.

\section{unitermos}

Terapia fotodinâmica

Apoptose

Mitocôndria

\section{Introduction}

In photodynamic therapy (PDT), visible light activates a photosensitizing drug accumulated in tumor or other abnormal tissue ${ }^{(10,13,25)}$. The interaction between the excited photosensitizer and molecular oxygen produces singlet oxygen $\left({ }^{1} \mathrm{O}_{2}\right)$ as well as other reactive oxygen species (ROS) to induce cancer cell death $\left.{ }^{2}, 24,42,44,49\right)$. The mode of cell death by PDT is often apoptosis, and substantial evidence supports the involvement of mitochondria in this process ${ }^{(32}$, 65-67). During apoptosis, mitochondria release soluble proteins from the intermembrane space into cytosol.
These proteins are cytochrome $c$ (cyt $c)^{(21)}$, apoptosis inducing factor (AIF) ${ }^{(28)}$, and Smac/DIABLO ${ }^{(6)}$, which initiate downstream apoptotic signaling events.

\section{Apoptosis}

Programmed cell death (PCD) or apoptosis is a fundamental property of all multicellular organisms. The PCD, a gene-regulated form of cell death, occurs at different stages of growth, for example, to eliminate cells between developing digits or degeneration of neurons 
that fail to form proper cellular connections. Some cells also die during the organism's life cycle to regulate the size of the cell population in tissues. Additionally, when cells are confronted with environmental stresses, they can either be destroyed accidentally or can self-destruct using an active mechanism (apoptosis). This depends on the stress type or intensity ${ }^{(8)}$. Disturbed PCD plays a major role in diseases, such as cancer and neurodegeneration ${ }^{(50)}$. Excessive PCD can lead to degenerative diseases ${ }^{(56)}$, whereas insufficient apoptosis can lead to cancer ${ }^{(18)}$, because the organism loses control of the proliferation of a cell line ${ }^{(20)}$.

\section{Morphology of apoptosis}

The hallmarks of apoptosis in animal cells include chromatin condensation, internucleosomal DNA cleavage, cell fragmentation, and formation of apoptotic bodies. These bodies are removed by scavenging macrophages ${ }^{(17)}$.

DNA fragmentation in particular has been used as an indication of apoptosis, and several simple assays have been used to assess the extent of DNA fragmentation in apoptotic cells. For example, agarose gel electrophoresis ${ }^{(47)}$ is used to demonstrate the ladder patern of DNA wich is generated by endonucleolytic cleavage of genomic DNA into nucleosomalsize DNA of approximately 180 bases long (monomers) or oligonucleotides, which are multiples of 180 bases (oligomers) ${ }^{(69)}$.

\section{Mitochondrial apoptotic pathway}

Mitochondria have emerged as the central processing organelles in the majority of apoptotic pathways. Signals from cell surface death receptors or from damaged sites converge on mitochondria, leading to permeabilization of both mitochondrial membranes, dissipation of the inner membrane transmembrane potential and release of several apoptosis-related proteins, normally located in the intermembrane space of mitochondria ${ }^{(34,35,53)}$. Some of these proteins are AIF, Smac/DIABLO, cyt $c$, and certain procaspases. The release of apoptosis-related proteins and collapse of the mitochondrial transmembrane potential results from the opening of a large conductance channel known as the permeability transition pore complex (PTPC), which forms at contact sites of the outer and inner mitochondrial membranes ${ }^{(46)}$. This pore is formed by the transient complex of the voltage-dependent anion channel (VDAC) on outer membrane, the adenine nucleotide transporter (ANT) from the inner membrane and cyclophilin $D$ in the matrix. The inner membrane is normally impermeable to anions, but when the PTPC pore forms, it is thought that the rapid movement of water causes this compartment to swell, rupturing the outer membrane ${ }^{(27,28,62)}$.

AIF is localized in the mitochondria and released in response to PCD stimuli(28). This apoptosis-inducing factor moves directly to the nucleus, where it produces chromatin condensation and nuclear fragmentation ${ }^{(62)}$.

Smac/DIABLO is a recently identified novel proapoptotic molecule, which is released from mitochondria into cytosol during apoptosis. This mitochondrial protein performs a critical function in apoptosis by eliminating the inhibitory effects of IAPs (inhibitor of apoptosis proteins) $)^{(6)}$. The IAPs potently inhibit the catalytic activity of caspases ${ }^{(58)}$.

In apoptotic cells the cyt $c$, a component of the electron transport chain that shuttles electrons between complexes III and IV (cytochrome oxidase), is released from mitochondria into cytosol, and interacts with Apaf-1 and pro-caspase 9 to form a complex (apoptosome) ${ }^{(71)}$. This complex causes a caspase activation cascade that culminates in cell death characterized by apoptotic morphology $(39,41,73,74)$.

The cyt $c$ release in apoptotic cells is regulated by $B C L$ 2 family proteins. The first apoptotic gene (BCL-2) was discovered at the beginning of the nineties and was shown to be a supressor of apoptosis ${ }^{(26)}$. Other genes of the BCL-2 family were subsequently found on the basis of sequence similarities and physical interactions. This gene family is now composed of proapoptotic and antiapoptotic members ${ }^{(52)}$. Antiapoptotic members of this family, including BCL-2 and $B C L-X_{L}$, bind to the mitochondrial outer membrane and block AIF ${ }^{(64)}$, smac/DIABLO ${ }^{(1,63)}$, and cyt c efflux ${ }^{(3)}$.

The proapoptotic members of the BCL-2 family, such as Bax and Bid, promote the release of cyt $c$ and other proteins of the mitochondrial intermembrane space ${ }^{(3)}$. Bax functions directly on mitochondria to stimulate the release of cyt $c$ by forming a selective pore in the outer mitochondrial membrane, whereas others argue that Bax interacts with VDAC and/or ANT to facilitate opening PTPC (14, 29, 57). Evidence indicates that Bid induces conformational change in Bax that allows this protein to insert in the outer mitochondrial membrane and stimulate cyt $c$ release ${ }^{(15)}$.

The hydrolytic reactions of apoptosis are catalyzed by a family of proteases now termed caspases. The caspases are cysteine proteases (with cysteine in their active center) present in cytosol and activated by mitochondrial proteins released into cytosol, for example cyt $c$. These proteases activate other procaspases in a sequential cascade and are also activated 
by self-cleavage ${ }^{(46,62)}$. Caspases are often classified as initiator (caspases 2, 8, 9, 10), and effector (caspases 3, 6, 7). Initiator caspases, such as caspase 8 , activate effector caspases which in turn cleave and inactivate proteins that protect living cells from apoptosis, such as the DNA repair protein, poly (ADP-ribose) polymerase (PARP), ICAD/DFF45 (inhibitor of caspase-activated DNase, the nuclease responsible for DNA fragmentation), and antiapoptotic BCL-2 proteins. Other actions of caspases in apoptosis include cleavage of cytoskeletal proteins, including the lamins, proteins forming the nuclear lamina; cytoplasmic intermediate filaments, and several proteins involved in cytoskeletal regulation. This cleavage provokes disassembly of cell structures that depend on the cytoskeleton ${ }^{(46)}$

Figure 1 demonstrates a summary of the apoptotic mechanism mediated by mitochondria:

\section{Photodynamic therapy}

Photodynamic therapy is considered to have its origins in 1900 with the classic experiments by Raab. He observed that when paramecia were exposed to either sunlight alone or to the chemical acridine in the dark, no effects were observed. However, a lethal reaction occurred if the microorganisms were exposed to an acridine solution and sunlight concurrently. He described this toxic effect as dose dependent, with respect to both acridine concentration and duration of exposure to sunlight ${ }^{(68)}$.

Currently PDT is a clinical treatment that employs a combination of a photosensitizing compound, oxygen, and visible light for the therapy of several oncological, cardiovascular, dermatological, and ophthalmic diseases ${ }^{(38)}$.

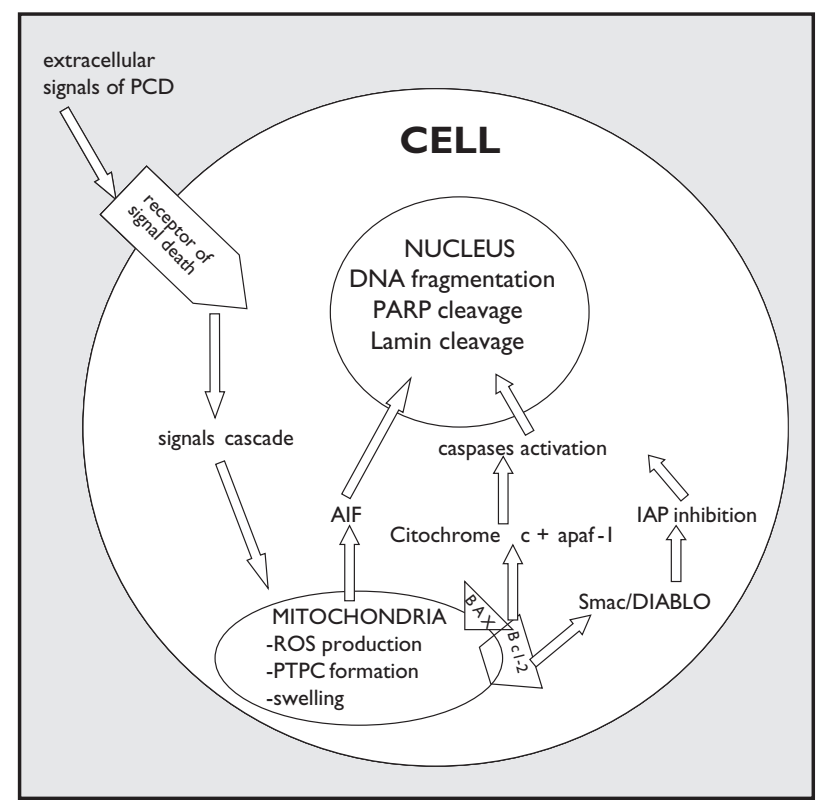

Figure 1 - Schematic representation of the programmed cell death (apoptosis) mediated by mitochondria. Mitochondrial ROS production, PTPC formation, and swelling provoke release of proapoptotic proteins (cyt c, AIF, and Smac/DIABLO) into cytosol. These proteins provoke caspase activation resulting in PARP and lamin cleavage. This event results in the DNA fragmentation

This technique is characterized by systemic administration of a photosensitizing drug, which is preferentially retained by diseased tissue. The photodestruction of the tumor is performed after visible light incidence ${ }^{(5,45)}$. The treatment results in the production of $\mathrm{ROS}$, such as ${ }^{1} \mathrm{O}_{2}$ and superoxide radical $\left(\mathrm{O}_{2}{ }^{\circ}\right)$, that provoke a sequence of oxidative events resulting in cancer cell death by apoptosis and/or necrosis ${ }^{(16,}$ 31) and eventual tumor ablation (Figure 2$)^{(5)}$.

The ROS, generated in PDT, damage biomolecules, such as proteins and lipids, generating photoproducts.

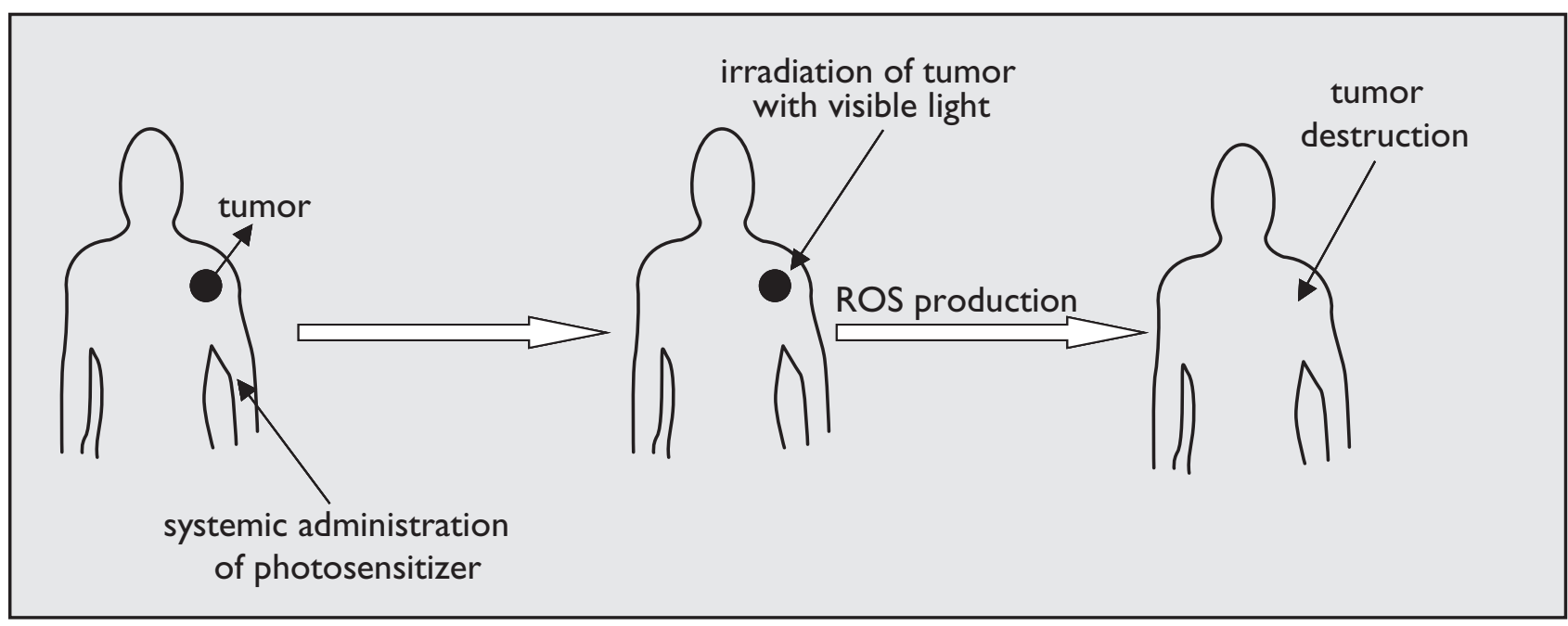

Figure 2 - Schematic of tumor therapy using a photosensitizing drug and visible light incidence 
The mechanisms of ROS production can be type I, type II or both. The superoxide and other radicals species are generated with the type I mechanism by electron transfer from photosensitizer, in the excited triplet state $\left(\mathrm{T}_{1}\right)$, to ground-state oxygen $\left({ }^{3} \mathrm{O}_{2}\right)$. Singlet oxygen is generated with the type II mechanism by energy transfer from phtotosensitizer $\mathrm{T}_{1}$ to ${ }^{3} \mathrm{O}_{2}{ }^{(19,59)}$ (Figure 3).

At present, only one phototherapeutic agent, namely Photofrin ${ }^{\circledast}$, has been approved for clinical use in cancer treatment ${ }^{(11)}$. This drug has been approved in Canada for the prophylactic treatment of bladder cancer. The Netherlands, France, Germany, and Japan have approved it in cases of early and advanced stages of cancer of the lung, the digestive tract, and the genitourinary $\operatorname{tract}^{(9)}$. In the United States of America, Photofrin ${ }^{\circledast}$ is the only photosensitizer approved by FDA (Food and Drug Administration) for clinical use in patients with esophageal and lung cancer ${ }^{(37}$, ${ }^{48)}$. However Photofrin ${ }^{\circledast}$ suffers from some drawbacks ${ }^{(12)}$. Firstly, it is a complex mixture of several partially unidentified porphyrins and it shows a poor selectivity in terms of target tissue/healthy tissue ratios. Secondly, its low extinction coefficients require the administration of relatively large amounts to obtain a satisfactory phototherapeutic response. Furthermore, it presents a high accumulation rate in skin, wich induces a prolonged cutaneous light ultrasensibility lasting for up to 6-8 weeks after PDT treatment. During this post-treatment period, patients have to stay out of sunlight to avoid a severe sunburn reaction ${ }^{(51)}$.

The problems encountered with Photofrin ${ }^{\circledR}$ have encouraged the development and the study of alternative photosensitizers, such as Hypericin, Foscan, NPe6, Lutecium Texaphyrin, Phtalocyanine Pc 4, and others ${ }^{(46,55,61)}$.

\section{Mitochondrial apoptotic pathway in photodynamic therapy}

Many of the photosensitizers currently in clinical or pre-clinical studies of PDT are localized in or have a major

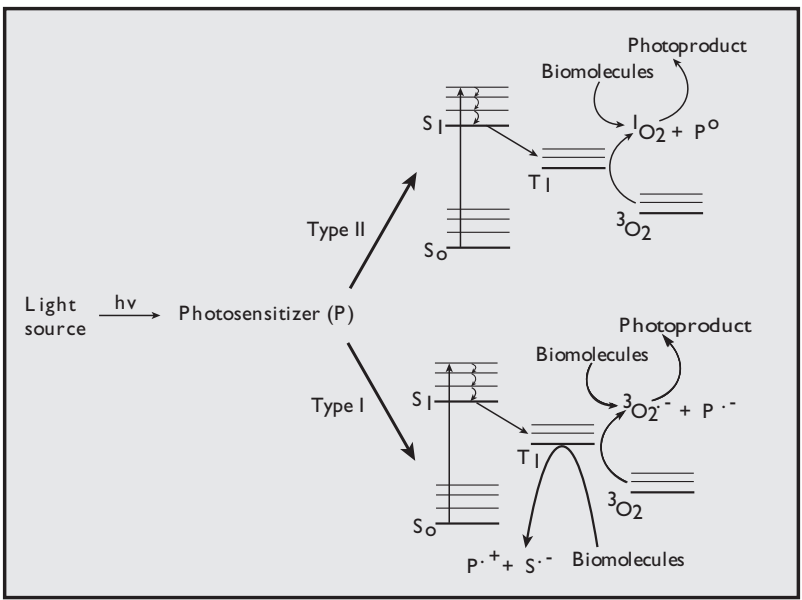

Figure 3 - Mechanisms (types I and II) of ROS generation by combination of light, photosensitizer $(P)$, and ground-state oxygen $\left({ }^{3} \mathrm{O}_{2}\right)$. Ground-state photosensitizer $\left(S_{0}\right)$ is irradiated with visible light generating excited singlet state photosensitizer $\left(S_{1}\right)$. $S$ can relax back to excited state photosensitizer $\left(T_{1}\right)$ generating superoxide radical $\left({ }^{3} \mathrm{O}_{2}^{*}\right)$ (mechanism type I) and/or singlet oxygen $\left({ }^{1} \mathrm{O}_{2}\right)$ (mechanism type II) $)^{(60)}$

influence on mitochondria, and PDT is a strong inducer of apoptosis in many situations ${ }^{(46)}$. There are many similarities between the mechanisms by which mitochondria regulate apoptosis and mechanisms by which PDT kills cancer cells. During PDT, ${ }^{1} \mathrm{O}_{2}$ attacks mitochondrial proteins and possibly alters their amino acid structures (Figure 4), thereby disrupting the proteins folding conformation. This may force them into other conformations that disrupt their normal functioning ${ }^{(43)}$.

Treatment with antioxidant inhibits cyt $c$ release, caspase 3 activation and PARP cleavage associated with PDT thereby supporting the contention that ROS generated by PDT induces apoptosis in cancer cells ${ }^{(40)}$. It has been demonstrated also that ${ }^{1} \mathrm{O}_{2}$, generated by irradiation of rose bengal with visible light, induces apoptosis in human promyelocytic leukemia HL-60 cells ${ }^{(72)}$. The PDT-treatment using rose bengal as the photosensitizer induces also apoptosis in human epidermal carcinoma A431 cells, but this event can be inhibited by ${ }^{1} \mathrm{O}_{2}$ scavengers and specific caspase inhibitors $^{(7)}$. The antiapoptotic protein BCL-2 is one

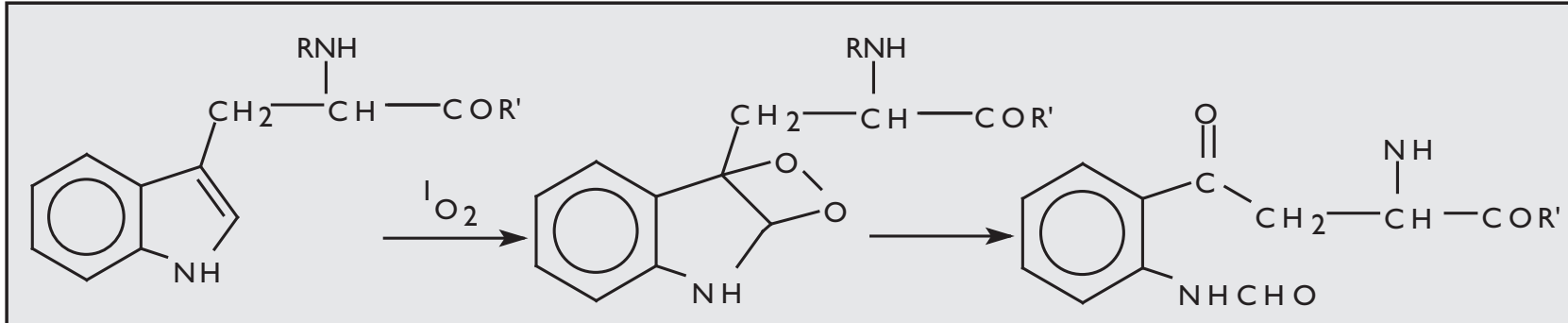

Figure 4 - Reaction of singlet oxygen with tryptophan 
target of PDT, and PDT damage to BCL-2 contributes to efficient induction of apoptosis ${ }^{(70)}$. It has been observed that PDT utilizing photosensitizer phtalocianine-4 (Pc-4) causes photodestruction of $\mathrm{BCL}-2$ in mitochondria. This event induces apoptosis in cancer cells but it can be prevented by singlet oxygen scavenger L-histidine. In this work photochemical damage was not observed in proapoptotic protein Bax, the VDAC, or the ANT (components of PTPC in mitochondria) ${ }^{(70)}$.

Formation of mitochondrial reactive oxygen species was detected within minutes when human epidermal carcinoma A431 cells were exposed to Pc 4 and 670$675 \mathrm{~nm}$ light. This was followed by mitochondrial inner membrane permeabilization, depolarization, swelling, and cyt $c$ release to cytosol, resulting in apoptotic cell death ${ }^{(36)}$. The irradiation of murine leukemia L1210 cells in presence of three photosensitizers (CPO, SnET2, and $m$-THPC), caused rapid decrease of the mitochondrial membrane potential, release of cyt $c$ into cytosol and activation of caspase-3. These effects were followed by the appearance of an apoptotic morphology. In this treatment BCL-2 photodamage was detected directly after irradiation but the proapoptotic protein Bax is not affected(30). Apoptosis was also induced in smooth muscle cells by the combination of the photosensitizer verteporfin and visible light. After PDT, an increase in mitochondrial cyt $c$ and AIF levels were detected in the cytosol. AIF translocated from mitochondria to the nucleus during the progression of apoptosis. In addition, cyt $c$ release provoked activation of multiple caspases during PDT ${ }^{(22)}$. Cleavage of PARP and DNA fragmentation were observed in tumor cells treated with the photosensitizer Hypericin. These events were preceded by cyt $c$ release, activation of initiator caspase- 8 , 9, 3, and Apaf-1 ${ }^{(4)}$.

PDT protocols employing lysosomal sensitizers induce apoptosis via a mechanism that causes cyt $c$ release prior to loss of mitochondrial membrane potential. It was demonstrated that lysosomal photodamage initiates mitochondrial-mediated apoptosis in murine hepatoma $1 \mathrm{c} 1 \mathrm{c} 7$ cells. In this work, fluorescence microscopy demonstrated that the photosensitizer Npe6 was localized in the lysosomes. Irradiation of cells with Npe6 induced rapid destruction of lysosomes, and subsequent cleavage/ activation of proapoptotic Bid, pro-caspase- 9 and 3 . This activation was provoked by release proteases from lysosomes. The activation of Bid caused the decrease of mitochondrial membrane potential and cyt $c$ release. This work demonstrated that photodamaged lysosomes trigger the mitochondrial apoptotic pathway by releasing proteases that activate Bid $^{(54)}$.

Photodynamic therapy using photosensitizer Pc-4 causes mitochondrial damage and induces apoptosis through the release of cyt $c$ to the cytosol. Another protein situated in the mitochondrial intermembrane space, Smac/DIABLO, is also released to the cytosol in response to apoptotic stimuli and promotes caspase activation by binding IAP(67). Recently, a study was made of the mechanism of cytotoxic effects of 5-aminolevulinic acidbased photodynamic therapy (ALA-PDT) on the human promyelocytic leukemia cell line HL60. The decrease of mitochondrial membrane potential was accompanied by a decrease in the ATP level, release of cyt c into cytosol, the activation of caspases 9 and 3, and the cleavage of PARP followed by DNA fragmentation. These data suggest that ALA-PDT activates the mitochondrial apoptotic pathway in cancer cells ${ }^{(23)}$.

In the screening of the new anticancer agents for use in PDT, it was discovered that a methanol extract of bamboo leaves induced rapid apoptosis in the human leukemia CMK7 cell line. This apoptosis was evaluated by monitoring the caspase 3 activation and DNA cleavage ${ }^{(33)}$. ATX-S10 (Na), a novel hydrophilic chlorin photosensitizer, shows good accumulation in tumors and is suitable for use in PDT. Recently, the mechanism of PDT-induced death using ATX$\mathrm{S} 10(\mathrm{Na})$ and diode laser in normal human keratinocytes (NHK) was investigated. ATX-S10 (Na)-PDT had induced apoptosis of NHK in two hours and the maximal effect was observed after six hours following irradiation. The effect was supressed by pretreatment of NHK with inhibitors of caspases 3, 6, 8 and 9, and western blotting revealed cytosolic release of cyt $c$ and AlF $^{(65)}$.

\section{Conclusion}

The importance of mitochondria as targets for the initiation of apoptosis by PDT has been demonstrated by several investigators. They found that many photosensitizers that bound to mitochondria induced apoptosis upon photoirradiation. In this treatment the irradiation with visible light results in the generation of large amounts of ROS which result in mitochondrial damage, PTPC formation and release of proapoptotic proteins into cytosol. These proteins cause the activation of caspases, resulting in DNA fragmentation and, finally, lead to death of tumor tissue by apoptosis (Figure 5). 


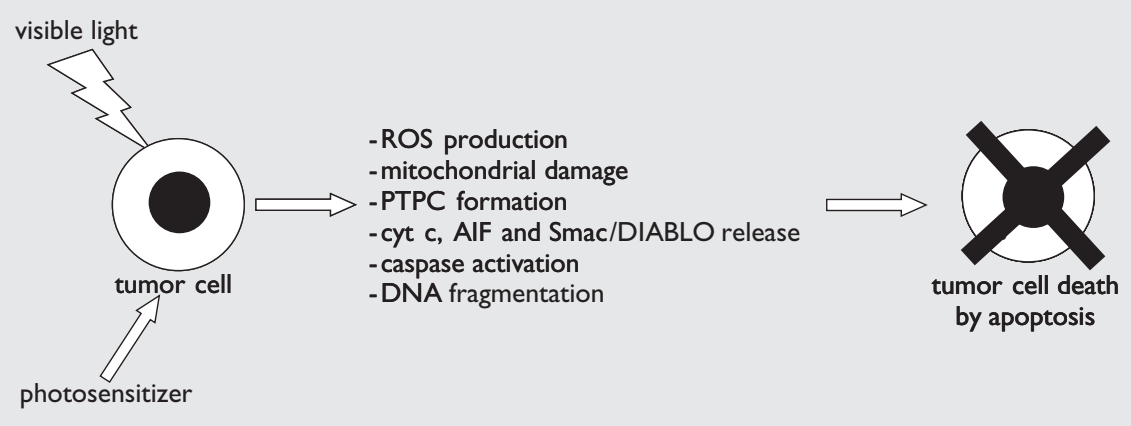

Figure 5 - Apoptosis in photodynamic therapy with participation of mitochondria

\section{Acknowledgements}

This research was supported by the Conselho Nacional de Desenvolvimento Científico e Tecnológico (CNPq),
Brasília, and the Coordenação de Aperfeiçoamento de Pessoal de Nível Superior (CAPES), Brasília. We also thank Gyda May for language assistance.

\section{References}

I.ADRIAN, C. et al. Apoptosis-associated release of Smac/DIABLO from mitochondria requires active caspases and is blocked by Bcl-2. Embo J, v. 20, n. 23, p. 6627-36, 2001 .

2. AGARWAL, M. L. et al. Photodynamic therapy induces rapid cell-death by apoptosis in 15178y mouse lymphoma-cells. Cancer Res, v. 5 I, p. 5993-6, 1991.

3. AHSEN, V. O. et al. Preservation of mitochondrial structure and function after Bid- or Bax-mediated cytochrome c release. J Cell Biol, v. I 50, n. 5, p. 1027-36, 2000.

4. ALI, S. M. et al. Hypericin induced death receptor-mediated apoptosis in photoactivated tumor cells. Int J Mol Med, v. 9 , n. 6, p. $601-16,2002$.

5. BONNETT, R. Photosensitizers of the porphyrin and phthalocyanines series for photodynamic therapy. Chemical Society Reviews, v. 24, p. 19-33, 1995.

6. CHAI, J. J. et al. Structural and biochemical basis of apoptotic activation by Smac/Diablo. Nature, v. 406, n. 6798, p. 85562, 2000.

7. CHAN,W.H. et al.Apoptotic signalling cascade in photosensitized human epidermal carcinoma A43I cells: involvement of singlet oxygen, c-Jun N-terminal kinase, caspase-3 and p2Iactivated kinase 2. Biochem J, v. 35I, p. 221-32, 2000.

8. DANON, A. et al. Plant programmed cell death: a common way to die. Plant Physiol Biochem, v. 38, p. 647-55, 2000.

9. DOUGHERTY,T. J. et al. Photodynamic therapy (review). J Natl Cancer Inst, v. 90, p. 889-905, 1998.

10. DOUGHERTY, T. J. An update on photodynamic therapy applications. J Clin Laser Med Sur, v. 20, p. 3-7, 2002.

I I. DOUGHERTY, T. J. Photodynamic therapy: basic principles and clinical application. New York: Marcel Dekker, 1992.

12. DOUGHERTY, T. J. Photosensitizers, therapy and detection of malignant tumors. Photochem Photobiol, v. 45, p. 879-89, 1987.
I 3. DOUGHERTY,T. J:; MARCUS, S. L. Photodynamic therapy. Eur J Cancer, v. 28, p. 1734-42, 1992.

14. ESKES, R. et al. Bax-induced cytochrome $C$ release from mitochondria is independent of the permeability transition pore but highly dependent on Mg2+ ions. J Cell Biol, v. I43, p. 217-24, 1998.

15. ESKES, R. et al. Bid induces the oligomerization and insertion of Bax into the outer mitochondrial membrane. Mol Cell Biol, v. 20, p. 929-35, 2000.

16. FABRIS, C. et al. Photosensitization with zinc (II) phtalocyanine as switch in the decision between apoptosis and necrosis. Cancer Res, v. 6I, n. 20, p. 7495-500, 2001.

17. FATH, A. et al. Barley aleurone cell death is not apoptotic: characterization of nuclease activities and DNA fragmentation. The Plant Journal, v. 20, n. 3, p. 305-15, 1999.

18. FICHER, D. E.Apoptosis in cancer therapy: crossing the threshold. Cell, v. 78, p. 539-42, 1994.

19. FOOTE, C. S. Definition of type I and type II photosensitized oxidation. Photochem Photobiol, v. 54, n. 5, p. 659, 1991.

20. GILCHRIST, D. G. Programmed cell death in plant disease: the purpose and promise of cellular suicide. Annu Rev Phytophatol, v. 36, p. 393-4|4, 1998.

21. GOGVADZE, V. et al. Cytochrome c release occurs via $\mathrm{Ca}^{2+}$ dependent and $\mathrm{Ca}^{2+}$-independent mechanisms that are regulated by Bax. J Biol Chem, v. 276, n. 22, p. 19066-71, 2001.

22. GRANVILLE, D. J. et al. Mitochondrial release of apoptosis-inducing factor and cytochrome c during smooth muscle cell apoptosis. American J Pathol, v. I59, n. I, p. 305I I, 200।.

23. GREBENOVA, D. et al. Mitochondrial and endoplasmatic reticulum stress-induced apoptotic pathway are acrivated by 5 -aminolevulinic acid-based photodynamic therapy in 
HL60 leukemia cells. J Photochem Photobiol B-Biology, v. 69, n. 2, p. 7I-85, 2003

24. HE, X.Y. et al. Photodynamic therapy with photofrin-ii induces programmed cell-death in carcinoma cell-lines. Photochem Photobiol, v. 59, p. 468-73, 1994.

25. HENDERSON, B. W.; DOUGHERTY, T. J. How does photodynamic therapy work. Photochem Photobiol, v. 55, p. 145-57, 1992.

26. HOCKENBERGY, D. M. et al. Bcl-2 is an inner mitochondrial membrane protein that blocks programmed cell death. Nature, v. 348, p. 334-6, 1990.

27. JONES, A. Does the plant mitochondria integrate cellular stress and regulate programmed cell death? Trends in Plant Sci Persp, v. 5, n. 5, p. 225-30, 2000.

28. JOZA, N. et al. Essential role of the mitochondrial apoptosisinducing factor in programmed cell death. Nature, v. 410 , p. 549-54, 2001.

29. JURGENSMEIER, J. M. et al. Bax directly induces release of cytochrome c from isolated mitochondria. Proc Natl Acad Sci USA, v. 95, p. 4997-5002, 1998

30. KESSEL, D.; CASTELLI, M. Evidence that $\mathrm{BCl}-2$ is the target of three photosensitizers that induce rapid apoptotic response. Photochem Photobiol, v. 74, n. 2, p. 318-22, 200 I.

3।. KESSEL, D.; LUO, Y. Photodynamic therapy: a mitochondrial inducer of apoptosis. Cell Death Differ, v. 6, n. I, p. 28-35, 1999.

32. KESSEL, D.; REINERS Jr.,.J.JApoptotic response to photodynamic therapy versus the $\mathrm{Bcl}-2$ Antagonist HAI4-I. Photochem Photobiol, v. 76, n. 3, p. 3। 4-9, 2002.

33. KIM, K. K. et al.A novel porphyrin photosensitizer from bamboo leaves that induces apoptosis in cancer cell lines. Anticancer Res, v. 23, n. 3B, p. 2355-63I, 2003.

34. KROEMER, G. et al. The mitochondrial death/life regulator in apoptosis and necrosis. Annu Rev Physiol, v. 60, p. 619-42, 1998.

35. KROEMER, G.; REED, J. C. Mitochondrial control of cell death. Nat Med, v. 6, p. 513-9, 2000.

36. LAM, M. et al. Photodynamic therapy-induced apoptosis in epidermoid carcinoma cells. J Biol Chem, v. 276, p. 4737986,2001 .

37. LASER MEDICAL RESEARCH FOUNDATION. Available at: [http://209.41.253.5:80/pdt@lmrf]. Accessed on: January 10, 2003.

38. LEVY, J. G.; OBOCHI, M. New applications in photodynamic therapy introduction. Photochem Photobiol, v. 64, p. 737-9, 1996.

39. LI, P. et al. Cytochrome $\mathrm{c}$ and dATP-dependent formation of Apaf-I/caspase-9 complex initiates an apoptotic portease cascade. Cell, v. 91, p. 479-89, 1997.

40. LI, R. et al. Rapid induction of apoptosis in human keratinocytes with the photosensitizer QLT0074 via a direct mitochondrial action. Apoptosis, v. 8, n. 3, p. 269-75, 2003.

4I. LIU, X. et al. Induction of apoptotic program in cell-free extracts: requirement for dATP and cytochrome c. Cell, v. 86, p. I4757, 1996.

42. LUO, Y. et al. Rapid initiation of apoptosis by photodynamic therapy. Photochem Photobiol, v. 63, p. 528-34, 1996.
43. MacDONALD, I. J.; DOUGHERTY, T. J. Basic principles of photodynamic therapy. J Porphyrins and Phthalocyanines, v. 5, p. 105-29, 2001.

44. MOAN, J.; BERG, K. Photochemotherapy of cancer-experimental research. Photochem Photobiol, v. 55, p. 931-48, 1992.

45. MOOR, A. C. E. Signaling pathways in cell death and survival after photodynamic therapy. J Photochem Photobiol B: Biol, v. 57, p. I- 13, 2000.

46. NANCY, L. et al. The role of apoptosis in response to photodynamic therapy: what, where, why, and how. Photochem Photobiol Sci, v. I, p. I-21, 2002.

47. NARENDRA, P. S. A simple method for accurate estimation of apoptotic cells. Experiment Cell Res, v. 256, p. 328-37, 2000.

48. NATIONAL CANCER INSTITUTE. Available at: [http://cancernet.nci.nih.gov]. Accessed on: January 12, 2003.

49. OLEINICK, N. L.; EVANS, H. H. The photobiology of photodynamic therapy: cellular targets and mechanisms. Radiat Res, v. I50, SI46-SI56, 1998.

50. PETIT, P.X. et al. Mitochondrial and programmed cell death: back to the future. FEBS Lett, v. 396, p. 7-13, 1996.

5 I. RAZUM, N. et al. Skins photosensitivity: duration and intensity following intravenous hematoporphyrin derivatives, HPD and DHE. Photochem Photobiol, v. 46, p. 925-8, 1987.

52. REED,J. C. Double identity for proteins of the Bcl-2 family. Nature, v. 387, p. 773-6, 1997.

53. REED, J. C. Mechanisms of apoptosis. Am J Pathol, v. I57, p. |4|5-30, 2000.

54. REINERS, J. J. et al. Release of cytochrome $c$ and activation of pro-caspase-9 following lysosomal photodamage involves Bid cleavage. Cell Death Differ, v. 9, n. 9, p. 934-44, 2002.

55. RIBEIRO, J. N. et al. Photooxidation of biomolecules in presence of octaethylporphyrin and vanadyl octaethylporphyrin. XXXII Reunião Anual da Sociedade Brasileira de Bioquímica e Biologia Molecular. Caxambu-MG, 2003.

56. SAVILL, J. Apoptosis and disease. Eur J Clin Invest, v. 24, p. 7I 523, 1994.

57. SHIMIZU, S. et al. Bcl-2 family proteins regulate the release of apoptogenic cytochrome $\mathrm{c}$ by the mitochondrial channel VDAC. Nature, v. 399, p. 483-7, 1999.

58. SHIOZAKI, E. N. et al. Mechanism of XIAP-mediated inhibition of caspase-9. Molecular Cell, v. I I, n. 2, p. 519-27, 2003.

59. SIBATA, C. H. et al. Photodynamic therapy: a new concept in medical treatment. Brazilian J Med Biol Res, v. 33, p. 869-80, 2000.

60. SILVA, A. R. Análise das propriedades fotossensibilizantes do In (III)- mesotetrafenilporfirina para uso em terapia fotodinâmica. Campinas-SP, 2003.Tese (mestrado) - Instituto de Química, UNICAMP.

6I. SILVA, A. R.; JORGE, R. A. Interactions studies of In (III)mesotetraphenylporphyrin with unilamelar lipidic vesicles and photoxidation mechanism of human erythrocytes. XXXII Reunião Anual da Sociedade Brasileira de Bioquímica e Biologia Molecular. Caxambu-MG, 2003.

62. SRAELS, L. G.; ISRAELS, E. D. Apoptosis. Stem Cells, v. 17, p. 306-13, 1999. 
63. SUN, X. M. et al. Bcl-2 and $\mathrm{Bcl}-\mathrm{x}(\mathrm{L})$ inhibit CD95-mediated apoptosis by preventing mitochondrial release of Smacl $\mathrm{DIABLO}$ and subsequent inactivation of $\mathrm{X}$-linked inhibitorof-apoptosis protein. J Biol Chem, v. 277, n. 13, p. II345-5 I, 2002.

64. SUSIN, S. A. et al. Bcl-2 inhibits the mitochondrial release of an apoptogenic protease. J Exp Med, v. I84, n. 4, p. |33|-4|, 1996.

65. TAKAHASHI, $H$. et al. Activation of two caspase cascades, caspase 8/3/6 and caspase 9/3/6, during photodynamic therapy using a novel photosensitizer, ATX-SIO(Na), in normal human keratinocytes. Arch Dermatol Res, v. 295, n. 6. p. 242-8, 2003.

66. USUDA, J. et al. Association between the photodynamic loss of $\mathrm{BCl}-2$ and the sensitivity to apoptosis caused by phthalocyanine photodynamic therapy. Photochem Photobiol, v. 78, n. I, p. I-8, 2003.

67. USUDA, J. et al. Promotion of photodynamic therapy-induced apoptosis by mitochondrial protein Smac/DIABLO: dependence on Bax. Photochem Photobiol, v. 76, n. 2, p. 217-23, 2002.
68.VIA, D. L.; MAGNO, S. M. Photochemotherapy in the treatment of cancer. Curr Med Chem, v. 8, p. 1405-18, 200 I.

69.WYLLIE, A. H. et al. Cell death: the significance of apoptosis. Int Rev Cytol, v. 68, p. 25I-306, 1980.

70. XUE, L. Y. et al. Photochemical destruction of the $\mathrm{Bcl}-2$ oncoprotein during photodynamic therapy with the phtalocyanine photosensitizer Pc 4. Oncogene, v. 20, n. 26, p. 3420-7, 2001.

7I. YANG, J. et al. Prevention of apoptosis by $\mathrm{Bcl}-2$ : Release of cytochrome c from mitochondria blocked. Science, v. 275, p. I 129-32, 1997.

72. ZHUANG, S. G. et al. Caspase-8 mediates caspase-3 activation and cytochrome $c$ release during singlet-oxygen-induced apoptosis of HL-60 cells. Experiment Cell Res, v. 250, n. I, p. 203-12, 1999.

73. ZOU, H. et al. An Apaf- I cytochrome c multimeric complex is a functional apoptosome that activates procaspase-9.J Biol Chem, v. 274, p. II549-56, 1999.

74. ZOU, H. et al.Apaf- I, a human protein homologous to C. elegans CED-4, participates in cytochrome c-dependent activation of caspase. Cell, v. 90, p. 405-13, 1997.
Mailing address

Renato Atílio Jorge

Instituto de Química da Universidade Estadual

de Campinas (UNICAMP)

Cidade Universitária Zeferino Vaz, Barão Geraldo

Caixa postal 6154

CEP 13083-970 - Campinas-SP

e-mail: rjorge@iqm.unicamp.br 